\title{
Balancing Motherhood and Career in STEM Jobs
}

Dr. Rituparna Bhattacharyya ${ }^{\dagger}$

\begin{abstract}
Proportion of women working in the hitherto male-dominated sectors such as Science, Technology, Engineering, and Maths (STEM) jobs are primarily low because of gender stereotyping and motherhood roles. Using the findings of the article titled Entitled to a Sustainable Career? Motherhood in Science, Engineering, and Technology published in the Journal of Social Issues, this report attempts to explain as to how STEM jobs can retain more women.
\end{abstract}

Key words: STEM, Career, Motherhood

\footnotetext{
${ }^{+}$Executive Editor, Journal Space and Culture, India; Independent Researcher and In Charge-Training and Development, Alliance for Community Capacity Building in North East India, North Shields, UK. Email: rituparna.bhattacharyya@accb.org.uk C2016 Bhattacharyya. This is an Open Access article distributed under the terms of the Creative Commons Attribution License (http://creativecommons.org/licenses/by/2.0), which permits unrestricted use, distribution, and reproduction in any medium, provided the original work is properly cited.
} 
DIO: $10.20896 /$ saci.v\%vi\%i.178

\section{Introduction}

It remains well documented that as a result of biological naturalisation of sex roles and stereotyping, women and girls all over the living planet continue to remain invisible in Science, Technology, Engineering and Maths (STEM). Latest United Nations (UN) statistics unfold that out of an estimated 58 million primary schoolgoing children, who are out of school, 31million are girls. While 1 in 9 men pursue Science for graduation, for women, it is only 1 in 14. Similarly, in the field of Engineering, while it is 1 in 5 men; for women, it is 1 in $20 .{ }^{1}$ Against these dismal statistics, the UN adopted the resolution $A / R E S / 70 / 212$ (draft A/70/474/Add.2) and declared 11 February 2016 as the first International Day of Women and Girls in Science with the theme "Transforming the World: Parity in Science" aimed at greater participation of women and girls in science by $2030 .^{2}$

Notwithstanding, it is often challenging for a career-oriented woman all over the place to "have it all"-career, children, marriage, and financial stability (Aveling, 2002; Baber and Monaghan, 1988; Bielby and Bielby, 1984; Bhattacharyya, 2009; 2013; Granrose and Caplan, 1996; Herman and Lewis, 2012; Hoffnung, 2004, 2011; Lahiri-Dutt and Sil, 2014; Novack and Novack, 1996, Sarma, 2008). The challenge is indeed far more in the maledominated sectors such as STEM jobs (Adya and Kaiser, 2005; Jacobs, 2005; Long and Fox, 1995; Herman and Lewis, 2012; Williams and Ceci, 2012). The debate about retaining more women in STEM jobs has been ongoing, and varied models are being put forward by scholars to retain more women in the same (Adya and Kaiser, 2005; Herman and Lewis, 2012). In this report, I put forward the findings as reported by Herman and Lewis (2012) in

\footnotetext{
${ }^{1}$ Women in Science, United Nations, Retrieved from: http://esa.un.org/undesavoice/2016-

03/Women_in_science.png

2 International Day of Women and Girls in Science 11 February, United Nations, Retrieved from:

http://www.un.org/en/events/women-and-girls-inscience-day/index.shtml
}

their article titled Entitled to a Sustainable Career? Motherhood in Science, Engineering, and Technology, who examined the lack of adequate career progress in case of mothers who worked reduced hours to balance their career and motherhood and suggested measures to fix the 'leaky pipeline'. In the next section therefore, I analyse the findings of Herman and Lewis (2012).

\section{Fixing the Leaky Pipeline}

Based on semi-structured interviews with 30 women and 8 men across three countriesNetherlands, France and Italy, Herman and Lewis (2012) questioned the rationale of participants' decisions to work for reduced hours. The theoretical ideas that guided this research included the notion of 'sense of entitlement', normative parental beliefs and the context of parental policies; and frameworks such as parenthood (especially motherhood) amongst other closely related variables.

Herman and Lewis (2012) probed into career and motherhood narratives of three women: Tineke, a Dutch mother-Senior Manager; Soraya, an Italian mother-Deputy Manager and Helene, a French mother-Deputy Director. These three career mothers worked as parttimers to begin with, but made strides gaining much success in advancing in their career ladder. They felt the sense of entitlement proselytised and favoured by their managers, which boosted their confidence and supported them in sustaining both their careers and carer roles.

Women in the STEM sectors apparently fail to break the 'glass ceiling' and continue to face vertical segregation. Data from the UK Commission for Employment and Skills (UKCES) suggests that the proportion of women in the digital workforce has plummeted from $33 \%$ in 2002 to $27 \%$ in 2015 . Seemingly, in the UK, the proportion of women working in the STEM sector constitutes merely $13 \%$ of the STEM workforce (Arnett, 2015). 
Table 1: Proportion of Women Workforce in Few Renowned Companies

\begin{tabular}{llll} 
& $\begin{array}{l}\text { Proportion of } \\
\text { women employees }\end{array}$ & $\begin{array}{l}\text { total } \\
\text { technical positions }\end{array}$ & $\begin{array}{l}\text { Percentage of women in } \\
\text { leadership roles }\end{array}$ \\
\hline Microsoft & 29.1 & 16.6 & 23 \\
\hline Google & 30 & 17 & 21 \\
\hline Facebook & 32 & 16 & 23 \\
\hline Twitter & 34 & 13 & 22
\end{tabular}

Sources: Twitter shares 2016 diversity goals for hiring women, underrepresented minorities (http://www.zdnet.com/); Facebook sees just one percent rise in female workers, despite diversity efforts(V3.co.uk); Google statistics show Silicon Valley has a diversity problem (2014, 29 May). The Washington Post; Microsoft says 29 percent of its employees are female (2014, 3 October). The Verge

Further, research conducted by Thomson practices are important norms to advance Reuters, McKinsey, Fortune 500 has shown companies that recruited more women (especially in the senior management/boards of directors) have outperformed in comparison to companies with less/no women in higher leadership. Table 1 illustrates the figures of women failing to make it to the top jobs.

The STEM companies have increasingly shown concern to hire and retain more women. However, studies reveal that women opting to 'have it all' (Aveling, 2002; Bhattacharyya, 2009; 2013; Wingfield, 2015) often fail to achieve progress and juggle to balance work and motherhood practices - "a part of the..." "leaky pipeline"" from which women and girls forsake career and education in different stages of life to sustain motherhood and family (Herman and Lewis, 2012: 767). As one woman scientist who continues to juggle between balancing her career and motherhood has commented: "One cannot resign from motherhood but the amount of time one devotes to the role is in one's own hands" (Wingfield, 2015). Arguably, "it is motherhood rather than gender per se that tends to be a key barrier, perceived as incompatible with normative professional careers" (Herman and Lewis, 2012: 768).

Herman and Lewis (2012) goes on to argue that the success of the three talented mothers in their research could be viewed as 'exceptional' rather than a 'norm' given the extraordinary level of support they received from their employers. While flexible or part-time working career for a talented mother in every sector, however, many STEM companies have failed to implement this norm. Hence, Katharine Zaleski and Milena Berry have launched PowerToFly, a jobsite to help women to reconnect with those employers who are willing to allow its employees work from home/flexible hours. ${ }^{3}$ Similar jobsites are wanted all over the place that would enable more qualified women work for STEM sectors. Additionally, it remains paramount for the employers to lend the level of support, sensitivity and sense of entitlement to those mothers (fathers) who are in their motherhood/caring roles. Therefore, in order to fix the "leaky pipeline", perhaps, the line manager should be expected to respond sensitively and empathetically to concerns raised by employees, who are also in caring roles. For this, they should be trained on sensitisation programmes addressing stereotypical attitudes and presumptions linked to motherhood. Further, implementation of motherhood-friendly practices-a platform, wherein not only the new mothers of the companies can share their thoughts and experiences of motherhood (and fatherhood), but also the senior role models, who worked as part-timers/flexible hours and have made successive progress are made easily noticeable and invited therein, to share their everyday challenges. This in turn could stimulate others

\footnotetext{
${ }^{3}$ Want More Women Working in Tech? Let Them Stay Home, Retrieved from:

http://www.wired.com/2015/04/powertofly/
} 
with "a greater sense of entitlement" to sustain both their career and caring roles.

\section{References}

Adya Monica and Kate Kaiser (2005). Early Determinants of Women in the IT Workforce: A Model of Girls' Career Choices, Information Technology \& People, 18 (3), 230-259.

Aveling, Nado (2002). 'Having it All' and the Discourse of Equal Opportunity: Reflections on Choices and Changing Perceptions, Gender and Education, 14 (3), 265-280.

Arnett, George (2015, 13 June). How Well Are Women Represented in UK Science?, The Guardian, Retrieved from: http://www.theguardian.com/news/datablog/2 015/jun/13/how-well-are-women-representedin-uk-science

Baber, Kristine M. and Patricia Monaghan (1988). College Women's Career and Motherhood Expectations: New Options, Old Dilemmas, Sex Roles, 19 (3), 189-203.

Bielby, D.D. and W. T Bielby (1984). Work Commitment, Sex-Role Attitudes and Women's

Employment, American Sociological Review, 49, 234-247.

Bhattacharyya, Rituparna (2013). Are We Empowered? Stories of Young Indian working Women, Saarbrücken. Germany: Lap Lambert Academic Publishing.

Bhattacharyya, Rituparna (2009). Examining the Changing Status and Role of Middle Class Assamese Women: Lessons from the Lives of University Students. PhD thesis, Newcastle University, UK.

Granrose, C.S. and E.E. Caplan (1996). WorkFamily Role Choices for Women in their 20s and 30s: From College Plans to Life Experiences, Westport: Praeger.

Herman Clem and Suzan Lewis (2012). Entitled to a Sustainable Career? Motherhood in Science, Engineering, and Technology, Journal of Social Issues, 68(4), 767-789.
Hoffnung, Michele (2011). Career and Family Outcomes for Women Graduates of Single-sex Versus Coed Colleges, Sex Roles, 65, 680-692.

Hoffnung, M. (2004). Wanting It All: Career, Marriage, and Motherhood during CollegeEducated Women's 20s, Sex Roles, 50 (9-10), 711-723.

Lahiri-Dutt, Kuntala and Sil Pallabi (2014). Women's 'Double Day' in Middle-class Homes in Small-town India, Contemporary South Asia, 1-17, DOI: 10.1080/ 09584935.2014.979762.

Long, Scott, J. and Mary Frank Fox (1995). Scientific Careers: Universalism and Particularism, Annual Reviews, 21, 45-71, DOI: 10.1146/annurev.so.21.080195.000401.

Novack, L.L. and D.R. Novack (1996). Being Female in the Eighties and Nineties: Conflicts between New Opportunities and Traditional Expectations among White Middle Class Heterosexual College Women, Sex Roles, 35, 57-77.

Sarma, Rituparna B. (2008). Marriage, Motherhood and Career Salience: Young Women in Contemporary Society of Assam. In A.K. Ray and BD Ray (eds.) Women Emancipation: Focus North East India. New Delhi: Om Publications, pp. 163-182.

Williams, Wendy, M. and Stephen J. Ceci (2012). When Scientists Choose Motherhood, American Scientist, Retrieved from: http://www.americanscientist.org/issues/pub/ when-scientists-choose-motherhood

Wingfield, Brenda (2015, 24 August). Juggling a Career and Motherhood: A Scientist Tells Her Story. The Conversation. Retrieved from: http://theconversation.com/juggling-a-careerand-motherhood-a-scientist-tells-her-story46352

Women and Work: The Facts, Retrieved from: http://gender.bitc.org.uk/researchinsight/WomenWorkFactsheet 